\title{
Virtue vs. virtue ethics
}

\section{Christoph Halbig}

\begin{abstract}
The present article sets out to defend the thesis that among the more or less familiar enemies or challenges an adequate theory of virtue has to cope with is another, less obvious one - virtue ethics itself. The project of establishing virtue ethics as a third paradigm of normative ethics at eye level with consequentialism and deontological approaches to ethics threatens to distort not just our ethical thinking but the theory of virtue itself. A theory of virtue that is able to meet the demands of a full-blown virtue ethics necessarily has to face three fundamental dilemmas and thus seems to fail as an adequate theory of virtue. And vice versa: An ontologically and normatively viable theory of virtue will be unsuited to provide a promising starting point for virtue ethics as the "third kid on the block" among the options of self-standing paradigms of normative ethics.
\end{abstract}

Keywords Virtue $\cdot$ Virtue ethics - Unity of the virtues · Anscombe $\cdot$ MacIntyre

\section{Introduction}

Talk of the renaissance of virtue has become commonplace in contemporary ethics. "After Virtue", the title of Alasdair MacIntyre's book from 1981, might still provide an apt characterization of the crisis of western civilization after the failure of what MacIntyre calls the "Enlightenment project"; in academic debates however, virtue is very much present not just within the confines of a so called virtue ethics but also in normative ethics, moral psychology and even meta-ethics and the theory of rationality (see Halbig and Timmermann (eds.) 2021). On the other hand, at closer

C. Halbig $(\square)$

UZH Institute of Philosophy, University of Zurich, Zollikerstrasse 117, 8008 Zurich, Switzerland

E-Mail: christoph.halbig@philos.uzh.ch 
inspection the slogan "renaissance of virtue" proves misleading in at least three respects:

First of all, it is not clear what the renaissance is supposed to be a renaissance of: Whereas early proponents of virtue like Elizabeth Anscombe and Philippa Foot (Anscombe 2005 [1958]; Foot 1978) relied on the idea of an Aristotelian tradition supposedly dominating both ancient and medieval ethics as their natural point of reference, the pluralistic and often antagonistic character of competing theories of virtue within ancient ethics (Platonic, Aristotelian and Stoic to name only the most prominent) and the existence of important strands of a theory and ethics of virtue outside the Western tradition (within Buddhism and Confucianism, for instance) has become increasingly obvious. ${ }^{1}$

Second, it seems questionable whether virtue has ever been in need of a rebirth: Even during the first half of the 20th century, the classical candidate for a period of almost total neglect of virtue, virtue was arguably very much present in ethical theory - from G.E. Moore's definition of virtue as "an habitual disposition to perform certain actions, which generally produce the best possible results" (Moore 1903, p. 172) in his Principia Ethica to William Frankena's attempt at a reconciliation of an ethics of rules with an ethics of virtue, highlighted in his famous slogan "principles without traits are impotent, traits without principles are blind" (Frankena 1963, p. 53) in his influential Ethics.

Third, by relying on the idea of a restitutio ad integrum, a return to a state that predates a history of decline (candidates for the culprits responsible for the decline range widely: from a law conception of ethics anchored in a Divine legislator as held by Judeo-Christian theism (G.E.M. Anscombe) to the Enlightenment project and its inherent contradictions both at the level of theory and of cultural practice (Alasdair MacIntyre), to name only two examples), the slogan of a renaissance of virtue tends to draw attention away from important challenges to a theory of virtue that have arisen within philosophical and psychological debates on the concept and nature of virtue - ironically exactly parallel to its alleged renaissance. How fundamental those challenges actually are I am going to discuss in a moment.

The main thesis I hope to make plausible here is that among the more or less familiar enemies or challenges an adequate theory of virtue has to cope with is another, less obvious one - virtue ethics itself. The project of establishing virtue ethics as a third paradigm of normative ethics at eye level with consequentialism and deontological approaches to ethics threatens to distort not just our ethical thinking but the theory of virtue itself. A theory of virtue, as I want to show, that is able to meet the demands of a full-blown virtue ethics necessarily fails as an adequate theory of virtue. And vice versa: An ontologically and normatively viable theory of virtue will be unsuited to provide a promising starting point for virtue ethics as the "third kid on the block" among the options of self-standing paradigms of normative ethics.

\footnotetext{
1 An overview of important strands of non-European traditions of virtue and virtue-ethics is provided by the chapters 24-28 of van Hooft et alii (eds.) (2014) and by the relevant entries in Part II of Snow (ed.) (2018).
} 
After providing some preliminary definitions of key terms and positions I am going to rely on in the following (1), I will proceed to review two strands of challenges that tend to undermine the very idea of a theory of virtue as a basic normative category (2). In the main part of my paper, I will then try to identify two main types of pressure that the project of virtue ethics puts on the theory of virtue, pressures it is unlikely to be able to meet for both independent reasons and for dialectical reasons related to the two strands of challenges just mentioned (3). I will conclude with a short résumé that pulls together the main threads of my arguments and draws some conclusions as to the dialectical situation the present theory and ethics of virtue finds itself in (4). Needless to say, I will have to rely on a very small selection of arguments and positions within a highly diversified field of enquiry. ${ }^{2}$ I nonetheless hope they are apt to make visible fundamental problems that transcend the internal ramifications of the various debates.

\section{Some distinctions and definitions}

Let us first distinguish between a theory of virtue, an ethics of virtue and virtue ethics: ${ }^{3}$ A theory of virtue explores the ontology and epistemology of virtue, its role in the theory of normativity and action, its relationship with other traits and faculties etc. An ethics of virtue on the other hand explores the role of virtue within an overall framework that takes other categories than aretaic ones as fundamental, for instance outcomes or moral rules. Virtue ethics proper on the other hand is based on the assumption that virtues and vices provide the fundamental ethical concepts.

The distinction between an ethics of virtue and virtue ethics helps for instance to disambiguate the slogan of a "renaissance of virtue" in at least one of the three

\footnotetext{
2 But isn't this a rather arbitrary selection that relies on an unduly narrow definition of virtue ethics? As against such a challenge it is, however, crucial to take into account the dialectical starting point of my line of argument: While it is true that all sorts of positions have been classified under the heading of virtue ethics, it seems to be undeniable that those that claim for themselves the status of a "third kid on the block", i.e. as a self-standing paradigm of normative ethics in opposition to consequentialism and deontology, provide if not a natural kind than at least an interesting sub-set of positions that deserves scrutiny in its own right. Given the very nature of such a project, this sub-set shares with consequentialism and deontology a reductionistic spirit. This spirit is emphatically not shared by some of the authors who are usually also discussed under the heading of virtue ethics. Two examples: (i) Eudaimonists individuate the virtues by their contribution to human flourishing while defending a moralized conception of that very flourishing which considers it as partially constituted (according to the Aristotelian position) if not as exhausted by (according to the Stoics) virtue. (ii) Christine Swanton's target-centered account of the virtues individuates the virtues by reference to their targets. These targets include however goods that for their very status as goods may themselves depend on aretaic considerations (i.e. pleasure viciously realized might be debarred form the status as a good and thus provide no legitimate target for virtuous action). (For a detailed discussion of Swanton's position, see my (2013), ch. 7). Whatever its virtues both in the theory of virtue and in normative ethics might be, accounts of the virtues such as these do not lend themselves as starting points for a project such as the one mentioned above. Instead, they do not just break with the reductionistic spirit of much of modern normative ethics but undermine the very opposition of e.g. virtue ethics and consequentialism by denying the very existence of non-aretaically definable basic goods on the one hand and self-standing virtues that require no reference to entities that carry independent evaluative and normative weight on the other. Thanks to an anonymous reviewer for raising this challenge.
}

${ }^{3}$ For this distinction see also Crisp (1996), p. 5-8; Adams (2006), p. 6f. and Halbig (2013), p. 11. 
respects just mentioned: What was indeed present in the first half of the 20th century were arguably ethics of virtue of different stripes, be they consequentialist like Moore's or deontological like Frankena's; what was lacking however were prominent examples of virtue ethics proper.

The basic idea of virtue ethics can be spelled out in two different ways:

For one strand of virtue ethics, aretaic concepts are fundamental in the sense that they win by default: If, as for instance G.E.M. Anscombe has famously argued, deontological concepts lose their conditions of intelligibility once the theistic framework of a divine law-giver has been rejected, they should simply be done away within our ethical thinking and be replaced by aretaic ones (Anscombe 2005 [1958], p. $179 \mathrm{ff} ; 192-194)$.

For another strand of virtue ethics, however, there might be no need for an elimination of deontological and consequentialist concepts as long as those concepts can be derived from aretaic ones which in turn prove to be both independent from those other kinds of concepts and fundamental. ${ }^{4}$ A virtue ethics proper of this noneliminativist strand claims to be able to provide an account of what makes an action right or wrong in the first place instead of dropping the subject of its deontic status and simply characterizing it in other, aretaic terms.

Against the background of this way of structuring the debate on virtue and virtue ethics, it becomes immediately obvious why philosophers who try to establish virtue ethics as a third paradigm in normative ethics next to consequentialism and deontology tend toward the last-mentioned option: Ethics of virtue have always been an integral part of those competing paradigms, so they are ipso facto unsuited to provide an alternative towards them; the eliminativist strand of virtue ethics on the other hand simply seems to fail to engage with questions that both consequentialism and deontology try to address: What is it, for instance, that makes an action right (permissible or obligatory) or wrong? Non-eliminativist virtue ethics, in case it succeeds, would make it possible to have it both ways: Providing an answer to those questions that proves superior to those given by its competitors precisely by relying on independent und fundamental aretaic concepts.

This in turn proves to be a challenging task. It is not met for instance by Rosalind Hursthouse's claim that

An action is right iff it is what a virtuous agent would characteristically (i.e. acting in character) do in the circumstances. (Hursthouse 1999, p. 28)

As Roger Crisp and others have shown (Crisp 2010, pp. 23 f.; van Zyl 2013, pp. $127 \mathrm{f}$.), such a claim might offer a criterion of right action by providing necessary and sufficient conditions for it; what it does not tell us is what it is that makes those actions right - consequentialists or deontologists might provide the answer to that question, thus relegating virtue ethics to an epistemic tool that leaves the substance of rightness unexplained. The brand of a so-called agent-based virtue ethics defended

\footnotetext{
${ }_{4}$ Such a project has been pursued most prominently by Michael Slote, cf. Slote (2001), p. 7.
} 
by Michael Slote on the other hand does fulfill this explanatory demand. He defines morally acceptable action as follows:

An act is morally acceptable if and only if it comes from good or virtuous motivation [...] or at least doesn't come from bad or inferior motivation [...]. (Slote 2001, p. 38)

Whether a non-eliminativist virtue ethics can actually succeed in this explanatory task without either underhandedly pruning the deontological concepts it aims to derive from aretaic ones so as to facilitate such a project, thus distorting the phenomena to be explained or smuggling deontic (or consequentialist) elements into the very virtues and vices it relies on as explanatorily basic is of course the key question. Its answer crucially depends on what an adequate theory of virtue would look like, quite independently of its suitability as a starting-point for a self-standing form of normative ethics.

\section{Two challenges for virtue}

I have pointed out above that - somewhat ironically - parallel to its so-called renaissance, the environment for virtue has become considerably hostile, actually more hostile than it ever was in the long history of the discourse on virtue and vice. Let me try to characterize very briefly two major challenges virtue-theory has to face in the current intellectual climate:

2.1. Whatever virtues are (various strands of theories of virtue give widely differing answers to that question), they seem to share at least three structural features that have been succinctly summarized by John Doris:

(1) Consistency: Character and personality traits are reliably manifested in traitrelevant behavior across a diversity of trait-relevant eliciting conditions that may vary widely in their conduciveness to the manifestation of the trait in question.

(2) Stability: Character and personality traits are reliably manifested in trait-relevant behaviors over iterated trials of similar trait-relevant eliciting conditions.

(3) Evaluative integration: In a given character or personality the occurrence of a trait with a particular evaluative valence is probabilistically related to the occurrence of other traits with similar evaluative valences. (Doris 2002, p. 22)

Empirical research however, as so-called situationists claim, ${ }^{5}$ has shown that the first of those structural features, the cross-situational consistency of character traits, is not even a remote option when it comes to the basic psychological make-up

\footnotetext{
5 For an overview of the various strands of situationism and a critical assessment see Sabini \& Silver (2005); Halbig (2013), pp. 108-141; Bates \& Kleingeld (2018).

6 The second feature is rather uncontroversial in both ancient and contemporary debates although it is obviously in need of being spelled out with regard to the notions of reliability and similarity it implies. The third feature will be discussed below in the context of the problem of how to account for verdictive jugedments on what to do.
} 
of most of us. ${ }^{6}$ Honesty towards one's near and dear might coexist comfortably with dishonesty on the job. Instead of virtues as global character traits, what we actually find are highly specific traits that are tied to situational clues, like "honesty towards the near and dear in relatively protected and stress-free environments". But consistency seems to be the very point of virtues - they make us precisely independent of the vagaries of changing circumstances and situational pressure. Most situationists admit that it is psychologically possible to acquire virtues in the traditional sense of term - but, as psychological research has shown, this proves to be a very rare phenomenon indeed.

So-called mixed trait theorists (cf. Miller 2013, part III; 2014, pp. $43 \mathrm{ff}$.) on the other hand defend the existence of cross-situational consistent traits as building blocks in the character of most of us - but the consistent traits we actually find are according to those theories evaluatively mixed - they combine both morally positive and morally negative aspects that resist any sorting out and thus do not only not correspond to traditional virtues and vices but do not even provide starting points for being transformed into them. Again, virtues and vices seem to be the wrong sort of entities to correspond with the basic structure of human personalities.

Those results of empirical research in social psychology and other behavioural sciences seem to put into question even virtue's role as an ideal that at least points us in the direction of moral progress even if rarely met within reality: If - as situationists hold - the cultivation of consistent traits in themselves or if - as mixedtrait theorists hold - the cultivation of consistent traits of an unequivocal aretaic valence prove psychologically over-demanding for most of us, it seems preferable to turn attention away from character and towards the engineering of situations and environments that help to disambiguate our local and normatively mixed traits in the desired direction. ${ }^{7}$ Although both the empirical basis on which situationism and mixed-trait theories rely and the normative consequences that draw on the basis of that evidence remain highly controversial, they have already succeeded in raising a question that had not even been asked in the history of at least Western ethics: Are virtues and vices an integral part of any adequate theory of human character in the first place?

2.2. Consequentialism and deontology still tend to answer this question in the positive - although negative answers seem to be perfectly compatible with the basic assumptions of those positions (one could, for instance, try to formulate an ethical theory that builds on either a mixed trait-psychology or on pairs of highly local character traits on the one hand and on situational clues on the other). The challenge they raise for the theory of virtue lies in the exactly opposite direction: Rather than eliminating the virtues as out of reach for most of us they offer a friendly takeover: Instead of simply providing a stipulative definition of virtue (as for instance Moore did in the passage of Principia Ethica mentioned above) in recent years both deontologist and consequentialists try to accommodate key features of virtues and vices that used to be addressed only by traditions of a virtue ethics proper within their own respective positions. An early example for such a move might have been

\footnotetext{
7 For the consequences to be drawn from situationism or mixed trait theories in ethical and political practice see Doris (2002), chap. 6; Miller (2014), chap. 8.
} 
Immanuel Kant himself - starting from his rather rigid, deontological definition of virtue as "Stärke der Maxime des Menschen in Befolgung seiner Pflicht" ("virtue is the strength of a human being's maxims in fulfilling his duty") in his Metaphysik der Sitten (Kant 1968 [1797], p. 394), he provided a hermeneutically surprisingly rich account of the virtues that has triggered a whole industry of character- und virtuefriendly scholarship not just in historical studies of Kantian philosophy but within contemporary versions of a broadly Kantian approach to ethics as well. ${ }^{8}$ Parallel efforts can be found within consequentialism.

Again it might seem (and at least to me it does indeed seem) highly questionable whether and to what extent such projects of a friendly take-over of virtue are likely to succeed. The overall frameworks of both consequentialism and deontology set close limits to the extent of such "friendliness": Consequentialism for instance can hardly avoid an emphasis on promoting as the fundamental mode of responsiveness of virtue at the expense of others like appreciation, respect or expressivity. ${ }^{9}$ Deontology on the other hand seems committed to focusing rather one-sidedly on the motivational role of virtue (it is not a coincidence that Kant in his Latin definition of virtue as fortitude moralis (Kant 1968 [1797], p. 405) defined the genus of virtue by just one of its species, and a secondary, executive one at that - motivational strength). Again, whatever the prospects for such a friendly take-over, one thing at least seems certain: Virtue ethics can no longer claim to be the "natural home" for an adequate theory of virtue. Indeed, as I am going to argue in the next section, it is not - virtue ethics proves just as dangerous to an adequate account of virtue as do consequentialism and deontology, but of course for reasons of its own that deserve closer scrutiny.

\section{Virtue, virtue ethics and the fundamentality condition}

If the project of a non-eliminativist virtue ethics as an alternative to consequentialism and deontology is to succeed, virtue ethics has to treat, as Michael Slote succinctly puts it, the "ethical status of actions as entirely derivative from independent and fundamental ethical/aretaic facts (or claims) about the motives, dispositions, or [the] inner life of moral individuals" (Slote 2001, p. 7). Slote's independence-condition seems rather uncontroversial: If, as for instance a consequentialist like Moore claimed, virtuous traits of character are ontologically dependent on the value of the outcomes those traits help to bring about, virtue ethics becomes part and parcel of a consequentialist ethics instead of an alternative to it. Virtues do have to carry an independent weight in determining the deontic status of action quite independently of consequentialist and deontological considerations. But how exactly is the aretaic supposed to be fundamental?

\footnotetext{
${ }^{8}$ For a comprehensive discussion of Kantian virtue ethics in contemeporary philospohy cf. Esser (2003); see also Thomas E. Hill (2008) for a discussion of the relationship between Kant's theory of virtue and virtue ethics.

9 For a definition and discussion of the various modes of moral responsiveness see Swanton (2003), pp. $21 \mathrm{ff}$.
} 
It is again Michael Slote who provides the most radical answer to that question: According to him, the moral goodness of a virtue like, for instance, benevolence is simply "intuitively obvious and in need of no further grounding" (Slote 2001, p. 38). He thus not just rejects, for instance, a eudaimonistic approach that individuates the virtues as (roughly) those traits that actualize our nature as rational beings that seek to realize their own flourishing - Slote denies that such an account of the virtues is even necessary. In the same vein, Linda Zagzebski recently characterized her exemplarist moral theory as "a theory with a non-conceptual foundation - a collection of exemplars of admirability" (Zagzebski 2017, p. 103). Virtues are then defined as those "trait[s] we admire in an exemplar" (Ibid., p. 105). She sees no need for any further criterion "other than applying our disposition to admiration suitably tested by reflection" (Ibid., p. 107) in order to separate the dispositions we call virtuous from the non-virtuous.

The fundamental problem with both Slote's and Zagzebski's approach to spelling out the fundamentality-condition is that it conflicts with both the ontology and the phenomenology of its own subject-matter, the aretaic. The goodness of core virtues like benevolence or compassion seems to be all but fundamental; to the contrary, it seems to depend on the badness of the unfulfilled needs and the suffering whose alleviation provides the very criterion for a successful exercise of those virtues. Pace Zagzebski, those virtues are not the objects of what we just happen to admire, they are in a normatively loaded way admirable - and the badness of unfulfilled needs or suffering cannot be dispensed with when accounting for their admirability. The phenomenology of virtuous deliberation bears out those ontological relations of dependence: What the compassionate person cares about is the alleviation of suffering, not the supposedly fundamental fact of exercising his own compassion. If it sticks with the fundamentality-condition, virtue ethics seems to be committed to just the same schizophrenia that Michael Stocker famously diagnosed as a basic weakness of its consequentialist and deontological competitors (Stocker 1976) what makes an action right must be banned from the first-personal perspective of the deliberating subject.

But why not weaken the fundamentality-condition along the lines recently suggested by Daniel C. Russell? According to Russell, "the notion of virtue's priority to an account of right action must be understood as also including virtue's priority, not necessarily to the notion of good outcomes, but to the notion that outcomes can bear on the rightness of action" (Russell 2009, p. 69f.). If Russell is right, virtues can well be themselves ontologically dependent on categories of other kinds like outcomes as long as the only way those outcomes can bear on the deontic status of actions is that of being part and parcel of the respective virtues. However this again seems incompatible with the phenomenology of virtuous action: If a viciously motivated action succeeds in alleviating someone else's pain, the target of compassion is met; such an action (to draw on a distinction suggested by Christine Swanton (2003, pp. $238 \mathrm{ff}$.)) might not qualify as "from virtue", but it does qualify as "virtuous" simply because it was aimed at and has resulted in the right outcome. The normative role of outcomes does not seem entirely conditional on the virtues after all. 
For lack of space, I cannot go into the difficult question of how the fundamentality-condition might best be spelled out any further. Let me sum up my considerations so far in the form of a dilemma for the virtue-ethicist:

She may either stick to the fundamentality-condition. In that case, her account contradicts basic features not just of the phenomenology of virtue; she even seems unable to account for the very normativity of aretaic facts that is absolutely indispensable if her project is to get off the ground.

Or she may weaken the fundamentality-condition. In that case, it seems inevitable to admit that outcomes or deontic constraints do normative work of their own not just in determining the deontic status of actions but also by individuating the virtues and vices themselves, thus undermining the key project of virtue ethics to provide a self-standing alternative to consequentialism and deontology.

This dilemma however seems not to be the only one the virtue-ethicist faces. Another dilemma results from the fact that "rightness" or "wrongness" are verdictive facts about action. The question of rightness or wrongness comes up, as Linda Zagzebski rightly emphasizes, "in contexts in which we want a verdict on what to do in a given situation" (Zagzebski 2017, p. 198). Even if we take for granted that their deontic status is settled by aretaic facts, the problem needs to be addressed of how virtues (and vices) interact so as to arrive at such a verdict. Again, aretaic fundamentalists like Slote and Zagzebski seem simply to refuse to give an answer: For Slote, a "balance" between the various virtuous dispositions springs from "a good heart that seeks to do good for and by people" (Slote 2001, p. 42); for Slote, rational reflection on the credentials of such a verdict even becomes in itself a symptom for a lack of love and thus of a vicious disposition. A virtuous person, according to Slote, seems to be ipso facto not in need of (non-instrumental) reflection. Zagzebski, on the other hand, shows herself more friendly towards deliberation when she provides the following definition of an overall right act:

A right act for $\mathrm{A}$ in some set of circumstances $\mathrm{C}$ is what the person with phronesis (persons like that) would characteristically take to be most favored by the balance of reasons for A in circumstances C. (Zagzebski 2017, p. 201)

Zagzebski's account however runs in a very tight circle: The reasons to be considered within moral deliberation are in turn defined as "whatever an exemplar takes to be relevant to moral judgment" (Zagzebski 2017, p. 203). All of this leaves open crucial questions that have been discussed in the theory of virtue at least since Plato: Are all the virtues compatible with each other? If not, on what basis are we to decide conflicts between the claims of, say, kindness and justice? If they are compatible, do they actually require each other, as the Aristotelian theory of the unity of the virtues (antakolouthia, connexio virtutum) implies? The link that binds together the ethical virtues in that tradition while in its turn presupposing them is of course the intellectual virtue of practical wisdom (phronesis, prudentia).

The unity of the virtues seems both to be supported by the phenomenology of virtue - it explains for instance why there is no such thing as acting too generously or too justly - and it also looks like just the thing the virtue-ethicist needs in order to 
come up with a convincing reconstruction of the verdictive judgment of rightness in aretaic terms: It makes sure that the virtues do not pull in opposite and irreconcilable directions by allowing for instance that precisely the omission of a brave act may count as a genuine expression of courage while still acknowledging its normative claims for instance in the gestures or in the emotional set-up that accompanies such an omission. An appropriate responsiveness to reasons seems - far from being pace Slote a symptom of a lack of genuinely virtous traits - to be constitutive of virtue. The interconnectedness of the virtues duly reflects the holistic nature of those reasons: An exclusive focus on e.g. reasons of justice seems insufficient to guarantee even just action.

At this point however, not just one, but two dilemmas loom large for the virtueethicist who unlike Slote and Zagzebski relies on a rationally guided (via phronesis) unity of the virtues that in turn allows to account for verdictive judgments on the rightness or wrongness of actions. The first one is simply the one we are already familiar with: The reasons the virtues respond to - which include both consequentialist und deontic considerations - threaten to pull their own normative weight, demoting the virtues to transmitters of normativity instead of generating it. The second dilemma comprises the two horns of either dropping the unity of the virtues-thesis and thus falling back into a rather simplistic intuitionism as to how moral verdicts are reached (such as the emotional one held by Michael Slote), or of holding on to the unity-thesis and thus being stuck with what might be a normatively convincing ideal, but which proves for most of us impossible to realize in our psychological make-up.

It is no coincidence that the unity-thesis has almost unanimously been rejected by early proponents of the renaissance of virtue form Bernard Williams to Alasdair MacIntyre. ${ }^{10}$ If having one virtue requires possessing all the others, one single blind spot will imply the absence of virtue across the board. Again, this second horn of the dilemma might seem acceptable if one is ready to accept a strict distinction between a theory of rightness on the one hand and a theory of how to arrive at the right moral decisions on the other: The rightness of an act might be fixed by largely counterfactual reflections on how the phronimos who embodies all the virtues would act in the situation (or would advise the somewhat less phronimos or outrightly vicious to act), whereas all others would have to turn to the advice of the very few real or imagined phronimoi. But this seems hardly in keeping with the spirit of virtue ethics as a self-standing normative theory: How can a relation to hypothetical motives make an action overall virtuous and thus right? If it is no longer the actual virtuous character of the agent that does the work in determining the deontic status of his actions, but the hypothetical character of a phronimos realizing the full antakolouthia/connexio of the virtues, then, as Tom Hurka aptly put it, "a requirement of true belief [i.e. with regard to what it means to act rightly here and now], which is needed for acceptable implications, ends up doing all the work" (Hurka 2001, p. 230).

10 Cf. Geach (1977), p. 163; MacIntyre (1995), p. 240; Bernard Williams even considers its falsity as platitudinous, cf. Williams (1985), p. 36. In the last two decades the unity of the virtues has made a remarkable comeback, much of it inspired by the work of Anselm W. Müller, cf. Müller (1998) and Müller (2004). 
A third difficulty that results from the fundamentality-condition and that unfortunately I cannot go into any further for lack of space concerns the reasons the agent has for acting rightly. Again a dilemma looms large for the virtue ethicist: To the extent that he sticks with the fundamentality condition, his candidates for that status of fundamental aretaic states (be they self-standing traits devoid of any connection to eudaimonia or the hypothetical 'model' of the phronimos adjudicating on behalf of the actual agent) look singularly unsuited for the role of providing the actual agent with convincing normative and motivational reasons for performing the right action. Softening the fundamentality-condition and reintroducing for instance eudaimonia so as to underscore the normative credentials of right actions however would immediately raise the question of why one should not rely on eudaimonia in the individuation of virtues as well which would of course undermine the selfstanding character of virtue ethics.

\section{Conclusions}

Let me try to come to some tentative conclusions: What seems certain is that the overall climate for virtue and virtue ethics has significantly changed both compared to their supposed heydays and to the period of relative neglect in the early and middle 20th century. We have seen that empirical research has put into question the role of virtuous (and vicious) traits in our psychological make-up in a much more fundamental way than was even imaginable before. On the other hand, virtue ethics can no longer claim to be the "natural home" of virtue: Consequentialism and deontology have become much more accommodating towards virtue than they used to. The central claim of my argument has not been that the eliminativist stance of situationists and mixed-trait theorists or the imperialist appropriations of virtue by consequentialism or deontology cannot be successfully resisted. I am quite convinced that they can. The main thrust of my paper was to make plausible the perhaps more surprising thesis that the attempts by virtue ethics of tailoring virtue to its own demands should be resisted just as well. What drives the project of virtue ethics as a "third kid on the block" is crucially to provide a distinctive criterion of rightness. It has been argued by many contributors to current ethical debates that virtue ethics leads to a serious distortion of deontic statuses instead of their successful reconstruction in its own terms. But the same holds for the virtue side of the equation: In order to realize its aspiration, virtue ethics requires a theory of virtue that looks both unconvincing in itself and in respect to the phenomenology and ontology of virtues and makes virtue unnecessarily and dangerously vulnerable to attacks from its opponents: To fit with the virtue ethicist's agenda, the virtues have to look normatively and ontologically self-contained in order to meet the condition of fundamentality. On the other hand, the virtue ethicist has to rely on some version of the unity of the virtues so as to be able to reach verdicts on the deontic status of an action in a non-arbitrary way. Both moves however are grist to the mill of the enemies of virtue: Situationists and mixed-trait theorists have pointed out the considerable challenges in becoming globally and unambiguously virtuous with regard to single virtues; realizing the interconnected net of all the virtues looks 
even less like a convincing or inspiring ideal, let alone a pervading reality in the psychological make-up of even a small number of people. Consequentialists and deontologists might argue that emphasizing the function of channeling external normativity rather than generating it from purely aretaic sources (which in addition in a consequentialist framework is quite compatible with ascribing some intrinsic values to virtuous traits) fits better with the phenomenology of virtue than the account presupposed by virtue ethics.

In her classic paper from 1958 "Modern Moral Philosophy”, G.E.M. Anscombe had called for a moratorium on ethical theory-building (she advocated no less than "banishing ethics totally from our minds" (Anscombe 2005 [1958], p. 188)) until we regain a firm grip on fundamental concepts of moral psychology and the theory of action like "intention", "wanting" and of course "virtue" itself. This might appear as an even better piece of advice now than when it was written: If virtue ethics proves to be a no less distorting influence on the theory of virtue than its competitors, then perhaps research into virtue should be done quite independently of its role in ethical theorizing. This however strikes me as simply hopeless: The weight virtues have to carry in our ethical thinking is not something external to them but part and parcel of their ontology. What should be dropped however is the commitment to the basic aspiration of virtue ethics to provide a distinctive and fundamental criterion of rightness. Freed from the distorting influence of this implicit or explicit agenda, the theory of virtue might gain the necessary elbow-room to resist attempts of being eliminated as well as attempts of a friendly take-over and to focus instead on the specific contributions aretaic considerations make to our ethical thinking.

Funding Open access funding provided by University of Zurich

Open Access This article is licensed under a Creative Commons Attribution 4.0 International License, which permits use, sharing, adaptation, distribution and reproduction in any medium or format, as long as you give appropriate credit to the original author(s) and the source, provide a link to the Creative Commons licence, and indicate if changes were made. The images or other third party material in this article are included in the article's Creative Commons licence, unless indicated otherwise in a credit line to the material. If material is not included in the article's Creative Commons licence and your intended use is not permitted by statutory regulation or exceeds the permitted use, you will need to obtain permission directly from the copyright holder. To view a copy of this licence, visit http://creativecommons.org/licenses/by/4. $0 \%$.

\section{References}

Adams, Robert M. 2006. A Theory of Virtue. Oxford: Clarendon Press.

Anscombe, G.E.M. 1958. Modern Moral Philosophy. Reprinted in Human Life, Action and Ethics. Essays by G.E.M. Anscombe, ed. Mary Geach, Luke Gormally, 169-194. Exeter: Imprint Academic 2005.

Bates, Tom and Pauline Kleingeld. 2018. Virtue, Vice, and Situationism. In The Oxford Handbook of Virtue, ed. Nancy E. Snow, 524-545. Oxford: Oxford University Press.

Crisp, Roger. 1996. Modern Moral Philosophy and the Virtues. In How Should One Live? Ed. Roger Crisp, 1-18. Oxford/New York: Oxford University Press.

Crisp, Roger. 2010. Virtue Ethics and Virtue Epistemology. Metaphilosophy 41: 22-40.

Doris, John M. 2002. Lack of Character: Personality and Moral Behaviour. Cambridge: Cambridge University Press.

Esser, Andrea Marlen. 2003. Eine Ethik für Endliche. Kants Tugendlehre in der Gegenwart. Stuttgart: Frommann-Holzboog.

Foot, Philippa. 1978. Virtues and Vices and Other Essays in Moral Philosophy. Oxford: Oxford University Press. 
Frankena, Wiliam K. 1963. Ethics. Englewood Cliff (N. J.): Prentice-Hall.

Geach, Peter. 1977. The Virtues. Cambridge: Cambridge University Press.

Halbig, Christoph. 2013. Der Begriff der Tugend und die Grenzen der Tugendethik. Berlin: Suhrkamp.

Halbig, Christoph and Timmermann, Felix. 2021. Springer Handbook of Virtue and Virtue Ethics. Springer Verlag.

Hill, Thomas E. 2008. Kantian Virtue and 'Virtue Ethics'. In Kant's Ethics of Virtue, ed. Monika Betzler, 29-59. Berlin/New York: Walter de Gruyter.

van Hooft, Stan et alii (ed). 2014. The Handbook of Virtue Ethics, London/New York: Routledge.

Hurka, Thomas. 2001. Virtue, Vice and Value. Oxford: Oxford University Press.

Hursthouse, Rosalind. 1999. On Virtue Ethics. Oxford: Oxford University Press.

Kant, Immanuel. 1797. Metaphysik der Sitten. In Gesammelte Schriften, academy edition, vol. 6, $203-493$. Berlin: de Gruyter 1968. English translation: Kant. The Metaphysics of Morals. Translated and edited by Mary Gregor. Cambridge: Cambridge University Press 1996.

MacIntyre, Alasdair. 1995. Der Verlust der Tugend. Zur moralischen Krise der Gegenwart, translated by Wolfgang Riehl. Frankfurt/Main: Suhrkamp. First edition in English: After Virtue. A Study in Moral Theory. Notre Dame: University of Notre Dame Press 1981.

Miller, Christian B. 2013. Moral Character: An Empirical Theory. Oxford: Oxford University Press.

Miller, Christian B. 2014. Character and Moral Psychology. Oxford: Oxford University Press.

Moore, George Edward. 1903. Principia Ethica, Cambridge: Cambridge University Press.

Müller, Anselm W. 1998. Einheit der Tugend oder Einheit der Tugenden? Eine aristotelische Alternative zu Nicolai Hartmanns Position. Theologie und Philosophie 73 (2): 173-195.

Müller, Anselm W. 2004. Aristotle's Conception of Ethical and Natural Virtue. In Was ist das für den Menschen Gute? Ed. Jan Szaif und Matthias Lutz-Bachmann, 18-53. Berlin: De Gruyter.

Russell, Daniel C. 2009. Practical Intelligence and the Virtues, Oxford: Clarendon Press.

Sabini, John and Silver, Maury. 2005. Lack of Character? Situationism Critiqued. Ethics 115: 535-562.

Slote, Michael. 2001. Morals from Motives, Oxford/New York: Oxford University Press.

Snow, Nancy (ed). 2018. The Oxford Handbook of Virtue, New York: Oxford University Press.

Stocker, Michael. 1976. The Schizophrenia of Modern Ethical Theories. The Journal of Philosophy 73, 453-466.

Swanton, Christine. 2003. Virtue Ethics: A Pluralistic View. New York: Oxford University Press.

Williams, Bernard. 1985. Ethics and the Limits of Philosophy. London: Fontana.

Zagzebski, Linda. 2017. Exemplarist Moral Theory. New York: Oxford University Press.

van Zyl, Liezl. 2013. Virtue ethics and right action. In The Cambridge Companion to Virtue Ethics, ed. Daniel C. Russell, 172-196. Cambridge: Cambridge University Press. 